\title{
Loan Diversification, Market Concentration, and Stability in the Indonesian Banking Industry
}

\author{
Nabila Sheila Meutia, Dony Abdul Chalid* \\ Department of Management, Universitas Indonesia, Depok, Indonesia \\ *Corresponding author. Email: donny.abdul@ui.ac.id
}

\begin{abstract}
This study aims to investigate the impact of loan diversification, market concentration, and the interaction effect of loan portfolio diversification and market concentration on banks' stability in Indonesia. The observation includes 62 commercial banks from Indonesia with an annual data period of 2010-2017. By employing a panel regression technique with fixed effect models, the findings suggest that loan portfolio diversification decreased bank stability. However, market concentration does not significantly affect bank stability. The results of this study also indicate that the stability of diversifying banks may differ in concentrated and less concentrated markets.
\end{abstract}

Keywords: Diversification, Stability, Concentration, Bank

\section{INTRODUCTION}

The global financial crisis of 2008/2009 created the momentum that led to reforms in banking regulations. Previous studies showed that excessive bank risk-taking is one of the main causes of financial crises (Beck et al. 2006; Acharya and Naqvi 2012). The crisis phenomenon shows that it is increasingly important for each country to maintain financial system stability, including maintaining the performance and stability of the banking sector. In addition, the financial crisis also raised the banking sector's awareness to better maintain credit exposure to minimize risks from its loan portfolio. One of the ways that banks can maintain credit exposure is to diversify their credit portfolios. The traditional view in banking also supports the statement that diversification can improve bank performance.

Research on the impact of diversification strategies on bank performance has not found consensus. Some studies showed that a loan diversification strategy has a positive influence on the stability of the banking sector. In contrast, other studies showed different findings, where diversification did not always have a positive impact on bank performance. A diversification strategy is believed to be able to provide benefits in the form of economies of scale and reductions in a portfolio's volatility. In contrast, the corporate finance literature indicates that banks are better focused on distributing their loans to certain types of sectors to maximize their risk management expertise in certain fields.
In addition to loan diversification, previous studies also stated that the structure of bank markets has a significant influence on banks' financial conditions. Two theoretical views exist on the influence of market concentration on bank stability, namely, "concentrationstability" and "concentration-fragility." The first term indicates that a more concentrated market results in a more stable bank. Banks that are in a concentrated environment with a low level of competition have a greater chance of earning profits and a higher capital buffer. Conversely, the "concentration-fragility" view indicates that a more concentrated market results in a more vulnerable market to fragility. The implicit policy of "too big to fail" allows large banks to easily obtain subsidies, thereby ultimately encouraging them to take higher risks.

Previous studies on the influence of diversification strategies and market concentration on bank performance still generate different conclusions. Considering the financial system in Indonesia, which is strongly dependent on the banking system, the authors are motivated to examine the effect of loan diversification, market concentration, and the interaction between the two variables on bank stability. Most empirical studies only focused on the individual effect of either loan diversification or market concentration on bank performance. This study suggests that diversification in concentrated and less concentrated 
markets can have different effects on stability. However, studies that considered the effect of interactions between the two variables on bank performance are very limited.

The remainder of this paper is organized as follows. Section II reviews the relevant studies on loan diversification, market concentration, and bank stability. Section III provides our dataset and a brief explanation of the method. We provide empirical results and a discussion in Section IV and concluding remarks in Section V.

\section{LITERATURE REVIEW}

\subsection{Loan Diversification and Stability}

Traditional banking theory states that banks as supervisory delegations must diversify their loan portfolios to reduce the possibility of failures. By diversifying, banks can minimize the impact of idiosyncratic shocks on their loan portfolios. Meanwhile, banks that do not diversify tend to be more vulnerable to economic volatility in areas in which they focus their activities (Winton 1999; Tabak et al. 2011). This statement is also in line with basic portfolio theory, which indicates that a portfolio's total volatility decreases if the components in the portfolio have a low or negative correlation. Thus, banks can implement loan diversification strategies based on different types of uses and types of sectors to reduce the risks that they face (Shim, 2019).

Several empirical studies provided results that support traditional banking theories. Rossi et al. (2009) showed that, in Austria, loan portfolio diversification can reduce risks by the amount of the provision for bad loans owned by banks. Then, Sanya and Wolfe (2011) found that diversification in interest income-generating activities can increase risk-adjusted profits and reduce the insolvency risk of the banking sector in developing countries. Previous research linking loan diversification to bank stability by Shim (2019) using commercial bank data in America showed a positive influence, which is similar to the theoretical framework that banks can reduce their financial fragility by diversifying their loan portfolios. According to Shim (2019), by diversifying into different types of loans, banks can achieve economies of scope. A bank has specific information on its clients, enabling the bank to use this information to better assess the credit risk of prospective borrowers. Thus, banks can also improve the quality of their loans (Baele et al. 2007).

In contrast to traditional theory, the corporate finance literature stated that companies must concentrate on certain activities and sectors to take advantage of or benefit from their expertise in a sector. By specializing in several sectors, banks can increase their ability to screen borrowers, which results in better loan quality. According to Jensen (1986), diversification strategies also depend on manager incentives to gain personal benefits. Even when diversification reduces a company's value, managers can diversify if the potential for personal profits from diversification is greater than the cost to cover the decline in the company's value (Shim 2019). In this case, the diversification benefit can be limited by an increase in frictional costs attributable to the agency problem and, ultimately, can reduce the company's profit.

Some empirical studies supporting the literature on corporate finance include Stiroh (2006), Acharya et al. (2006), and Tabak et al. (2011). According to Stiroh (2006), diversification can reduce bank performance if the bank diversifies into a new sector or business line, and bank management lacks the expertise in that particular sector. Such a situation can increase insolvency risk and reduce bank returns. Other empirical studies, such as Acharya et al. (2006), showed that diversification increases risk in the Italian banking sector. Tabak et al. (2011) used commercial banks in Brazil to show that the concentration of loan portfolios could improve bank performance in terms of risk.

H1: Loan diversification significantly affects bank stability.

\subsection{Market Concentration and Stability}

The concentration-stability view states that banks operating in more concentrated markets tend to be wiser in terms of risk-taking. In this view, large banks are assumed to tend to conduct tighter credit assessments because quality credit will increase yields and create healthy financial conditions (Boot et al. 2000). One theory underlying this view is the franchise value hypothesis. The decline in franchise value tends to make banks less careful and incentivizes them to take higher risk to increase profits. Banks tend to allocate funds to riskier assets and loans with the expectation of "high risk, high return," thus decreasing stability (Lindawati \& Chalid 2017). In perfectly competitive markets (zero franchise value), because banks do not have the potential to generate profits, bankers relax their investment selection because they will not suffer losses. Conversely, when the bank has market power (positive franchise value), bank managers tend to be wiser in taking risks because they have the opportunity to obtain superior profits (Kasman \& Kasman 2015). With a higher franchise value, banks have lower incentives to take high risks, thus reducing moral hazard problems.

Some empirical studies that supported the concentration-stability view include Allen and Gale (2004), Boyd et al. (2004), and Jimenez et al. (2013). Allen and Gale (2004) argued that it is easier for regulators to supervise banks in a concentrated structure. Then, Boyd et al. (2004) found that the 
possibility of a financial crisis tended to be lower in concentrated markets than in less concentrated markets. Research by Jimenez et al. (2013) using Spanish banking system data indicated that lower market competition results in a more stable banking system, in accordance with the franchise value paradigm. Based on the risk-shifting paradigm, an increase in interest rates will increase borrowing costs, which will trigger borrowers to invest in riskier projects and, thus, the probability of default increases. This condition causes an increase in the number of bad loans and risks experienced by banks, thus decreasing bank stability (Berger et al. 2009). Thus, based on this paradigm, a higher level of market concentration encourages instability at the bank.

In contrast, the concentration-fragility view states that a concentrated market structure with fewer large banks is more vulnerable to financial fragility. The argument behind this view is that large banks in more concentrated markets tend to monopolize the market by increasing the loan rate to create moral hazard problems and eliminate debtors with the lowest risk (Berger et al. 2009). In addition, large banks in more concentrated systems have an easier time obtaining subsidies because of the implicit policy of "too big to fail." Therefore, the potential of these subsidies can incentivize large banks to take higher risks. Based on the risk-shifting paradigm, an increase in interest rates will increase borrowing costs, which will trigger borrowers to invest in riskier projects, thus increasing the probability of default. This condition will cause an increase in the number of bad loans experienced by banks, thus decreasing the bank's stability (Berger et al. 2009). Thus, based on this paradigm, a higher level of market concentration will encourage instability in a bank.

Empirical studies that support the view of concentration-fragility include Boyd and De Nicolo (2005), Uhde and Heimeshoff (2009), and Arogaki et al. (2011). Boyd and De Nicolo (2005) indicated a negative relationship between the concentration of banking markets and bank stability. In line with the view of concentration-fragility, they argued that banks in a more concentrated market and large banks tend to use their market power to obtain higher profits by setting higher lending rates. Using data from 25 countries in Europe, Uhde and Heimeshoff (2009) found a negative relationship between the concentration of banks and their financial stability. Then, Arogaki et al. (2011) found that, in the Eastern European region, competition in the banking sector could improve financial stability; in other words, market concentration reduces financial stability.

$\mathrm{H} 2$ : Market concentration significantly affects bank stability.

\subsection{Loan Diversification, Market Concentration, and Stability}

The theoretical framework of structure-conductperformance indicates that the market structure influences a company's performance through its behavior. Transaction cost theory indicates that the optimal level of diversification is determined by weighting additional costs of managing a diversified portfolio and income from diversification (Shim 2019). The theory indicates that when a company's competitive environment leads to an increase in the cost of supervision over diversified activities, companies reduce their diversification (Jones \& Hill 1988). When competition in a company's core business increases, the benefits of diversifying or providing managerial attention to non-core businesses decline (Shim 2019). This finding indicates that diversification is more beneficial for companies in less competitive and more concentrated markets. According to Shim (2019), banks that diversify in a more concentrated market have greater profit opportunities because of the economies of scope, market strength, and business synergy in a bank's portfolio. Thus, banks that diversify in concentrated markets tend to be more stable than banks that diversify in less concentrated markets.

In contrast, Hughes and Mester (1998) argued that large diversified banks usually take advantage of a reduction in the marginal costs of risk management for higher risk. Demsetz and Strahan (1997) had a similar opinion: in concentrated markets, large banks tend to utilize the benefits of their diversification to operate at higher leverage and take greater risks. A concentrated banking system can allow banks with market forces to set higher loan rates. Such a system also triggers borrowers to engage in riskier activities, thus ultimately adversely affecting banking performance. According to Caminal and Matutes (2002), weaker competition can direct banks to reduce credit ratings and provide larger loans, thereby increasing the probability of bank failures. Thus, banks that diversify in a more concentrated market can have lower financial stability than banks that diversify in a less concentrated market.

H3: Market concentration significantly affects the relationship between loan diversification and bank stability.

\section{RESEARCH METHOD}

This study uses a sample of 62 banks in Indonesia consisting of four state-owned banks, 21 foreign exchange banks, 13 non-foreign exchange banks, 5 mixed banks, 3 foreign banks, and 16 regional development banks (BPDs). The financial report of each bank was obtained from the Indonesian Banking Directory (DPI), which can be accessed through the Bank Indonesia website, whereas the annual report of 
each bank was obtained from their official websites. Other financial data were obtained from various sources, such as Thompson Reuters and Datastream.

This study uses proxy natural logarithms of Z-scores as the dependent variable, loan diversification and market concentration as independent variables, and several bank-specific and macroeconomic variables as control variables. Three estimation models are used in this research. The division of the model into three model specifications is intended to reveal the consistency of the influence of independent variables on the dependent variable and to avoid multicollinearity. These models will also use several control variables. The three models used in this study are as follows.

ModelA1: The effect of loan portfolio diversification on a bank's financial stability.

yit $=\alpha 0+\beta 1$ Divit $+\beta 2$ Controlit $+\varepsilon i t$

ModelA2: The effect of market concentration on a bank's financial stability.
(2)

yit $=\alpha 0+\beta 1 \mathrm{MCit}+\beta 2$ Controlit + eit

ModelA3: Interaction effect of loan portfolio diversification and market concentration on bank stability.

(3)

yit $\quad=\quad \alpha 0+\beta 1 \mathrm{MCxDivit}+\beta 2$ Controlit $+\varepsilon$ it

where $y_{i t}$ is the natural logarithm of the Z-score for each bank $i$ in period $t$, Divi,t is the loan diversification index for each bank $\mathrm{i}$ in period $\mathrm{t}$, MCt is bank market concentration calculated using the HerfindahlHirschmann Index in period $t$, MCxDivi, $t$ is the interaction variable between the loan diversification and market concentration of bank $\mathrm{i}$ in period $\mathrm{t}$, Xit is the matrix of control variables, and $\varepsilon_{i, t}$ is an error term.

Table 1 provides a list of the variables used in this research.

Table 1. List of variables

\begin{tabular}{|c|c|c|}
\hline Variable & Calculation & Reference \\
\hline $\begin{array}{l}\text { Bank's financial stability } \\
\text { (Ln Z-score) }\end{array}$ & $\operatorname{Ln}\left(\frac{R O A_{i t}+C A R_{i t}}{S D R O A_{i p}}\right)$ & $\begin{array}{l}\text { Yeyati and Micco (2007); Ashraf } \\
\text { et al. (2016); Shim (2019) }\end{array}$ \\
\hline $\begin{array}{l}\text { Loan diversification } \\
\text { (Div) }\end{array}$ & $\sum_{i=1}^{t}\left(\frac{\operatorname{Loan}_{i, u, t}}{{\text { Total } \operatorname{Loan}_{i, t}}^{2}}\right)^{2}$ & Tabak et al. (2011); Shim (2019) \\
\hline $\begin{array}{l}\text { Market concentration } \\
(\mathrm{MC})\end{array}$ & $\sum_{i=1}^{t}\left(\frac{\text { Deposit }_{i, u, t}}{\text { Total Deposit }_{i, t}}\right)^{2}$ & Ahsraf et al. (2016); Shim (2019) \\
\hline $\begin{array}{l}\text { Interaction variable } \\
\text { (McxDiv) }\end{array}$ & Div $x M C$ & Shim (2019) \\
\hline $\begin{array}{l}\text { Bank size } \\
\text { (Size) }\end{array}$ & Ln (Total Asset) & Kohler (2014) \\
\hline $\begin{array}{l}\text { Bank capital } \\
\text { (ETA) }\end{array}$ & $\frac{\text { Total Equity }_{i, t}}{\text { Total Asset }_{i, t}}$ & Kohler (2014) \\
\hline $\begin{array}{l}\text { Non-interest income share } \\
\text { (Nonint) }\end{array}$ & $\frac{{\text { Non Interest } \text { Income }_{i, t}}_{\text {Gross Income }} \text { Int, }}{\text { Grom }}$ & Kohler (2014) \\
\hline $\begin{array}{l}\text { Liquidity } \\
\text { (Liq) }\end{array}$ & $\frac{\text { Cash }+ \text { Due from Banks }_{i, t}}{\text { Total Asset }_{i, t}}$ & Shim (2019) \\
\hline $\begin{array}{l}\text { Annual GDP Growth } \\
\text { (GDP Growth) }\end{array}$ & $\frac{\text { Real } G D P_{t}-\text { Real } G D P_{t-1}}{\text { Real } G D P_{t-1}}$ & Shim (2019); \\
\hline BI Rate & BI 7-Day Repo Rate & Karim et al. (2016) \\
\hline
\end{tabular}




\section{RESULTS AND DISCUSSION}

Table II provides the descriptive statistics for each variable used in this study.

Table 2. Descriptive Statistics

\begin{tabular}{|c|c|c|c|c|c|}
\hline Variable & Obs. & Mean & Std. Dev & Min & Max \\
\hline LnZscore & 496 & 3.93263 & 1.114367 & 0.3497915 & 7.329997 \\
\hline Div & 496 & 0.5133697 & 0.1806161 & 0.0007721 & 0.9852819 \\
\hline MC & 496 & 0.0690348 & 0.0024863 & 0.0650191 & 0.0727243 \\
\hline MCxDiv & 496 & 0.03544 & 0.0125212 & 0.0000502 & 0.0716539 \\
\hline Size & 496 & 16.58038 & 1.735991 & 11.79689 & 20.84322 \\
\hline ETA & 496 & 0.140893 & 0.073752 & 0.0069852 & 0.8885945 \\
\hline Noninc & 496 & 0.1758474 & 0.1578697 & 0.0068741 & 0.944889 \\
\hline Liquidity & 496 & 0.2824977 & 0.0982079 & 0.0219786 & 0.6409484 \\
\hline GDP_G & 496 & 0.0549125 & 0.0053805 & 0.0487 & 0.0622 \\
\hline BI_Rate & 496 & 0.0646875 & 0.0108671 & 0.0425 & 0.0775 \\
\hline
\end{tabular}

The Hausman test as a formal test of the selection of panel data models shows that fixed effects are the right method for each model. The author also conducted several tests, such as the Breusch-Pagan test for heteroskedasticity and the Wooldridge test for autocorrelation. The results of the tests of each model showed heteroskedasticity problems and autocorrelation. Therefore, the author decided to use the fixed effect-generalized least squares (GLS) method to overcome these problems. The characteristics of heterogeneous banking data also encourage the author to use the GLS method. Table III provides the correlation matrix for the variables used in this research.

Tabel IV shows the regression results for all three models. The regression results in model 1 indicate that loan diversification significantly affects bank stability at the 5\% significance level. The negative coefficient indicates that an increase in loan portfolio diversification leads to a decrease in bank stability. Therefore, we can conclude that banks in Indonesia are better concentrated on certain types of loans to gain more stable and sustainable performance. Banks with a focused strategy can maximize their ability to increase profits. Management capabilities are needed to evaluate credit applications to allow banks to obtain a higher level of profitability. According to Bustaman et al. (2017), riskier loan types, such as investment loans, can generate higher income than working capital loans and consumption loans because banks can charge different interest rates on their loans based on the risk level. According to Laeven and Levine (2007), diversification strategies can trigger agency problems that arise from conflicts between managers and shareholders, where managers are incentivized to diversify and take more risk to maximize their personal benefits (Jensen, 1986). Basically, the benefits of diversification depend on the type of diversification activities carried out by the bank. If banks provide more loans to riskier sectors or borrowers, the benefits of diversification fade.

Thus, increasing diversification by banks can be said not to guarantee superior bank performance and lower bank risk. Banks in developing countries such as Indonesia need to consider wisely whether their choice to diversify also influences their effectiveness in monitoring credit disbursed. In addition, credit risk is strongly influenced by a bank's expertise in conducting assessments and monitoring the credit that they receive. Therefore, if a bank wants to diversify, it also needs to increase its investment in risk management to ensure effectiveness and efficiency in maintaining its loan quality.

Based on the regression test results for model 2, Indonesian banks' market concentration represented by an HHI proxy does not significantly affect bank stability. Non-significant results were also found in Hapsari (2017), Chen (2015), and Jimenez et al. (2013). Jimenez et al. (2013) found that standard measurements of market concentration, such as $\mathrm{HHI}$ and concentration ratios, did not affect bank performance. However, when using the Lerner Index, the findings are significant and support the franchise value paradigm. The results of this study imply that HHI may be less ideal in representing market concentration in this study. To overcome this weakness, further research can use other concentration proxies, such as Boone indicators and the Lerner Index, to measure market concentration. 
Table 3. Correlation Matrix

\begin{tabular}{|c|c|c|c|c|c|c|c|c|c|c|}
\hline & LnZscore & Div & $\mathrm{MC}$ & MCxDiv & Size & ETA & Liq & Noninc & GDP & $\begin{array}{l}\text { BI } \\
\text { Rate }\end{array}$ \\
\hline LnZscore & 1 & & & & & & & & & \\
\hline Div & -0.0266 & 1 & & & & & & & & \\
\hline $\mathrm{MC}$ & -0.0076 & -0.0082 & 1 & & & & & & & \\
\hline McxDiv & -0.0301 & 0.9943 & 0.0927 & 1 & & & & & & \\
\hline Size & 0.0377 & 0.4515 & 0.0649 & 0.4559 & 1 & & & & & \\
\hline ETA & 0.2303 & -0.0689 & 0.128 & -0.0556 & -0.3881 & 1 & & & & \\
\hline Liq & 0.0611 & 0.0037 & 0.0175 & 0.0047 & -0.0471 & -0.0154 & 1 & & & \\
\hline Noninc & -0.2293 & 0.2763 & 0.007 & 0.2758 & 0.445 & -0.1927 & -0.0241 & 1 & & \\
\hline GDP & -0.1036 & -0.0002 & -0.3199 & -0.0331 & -0.1936 & -0.081 & 0.0383 & 0.0022 & 1 & \\
\hline BI_Rate & 0.0322 & -0.0261 & -0.4834 & -0.0751 & -0.0207 & -0.0529 & -0.0233 & -0.0337 & -0.2034 & 1 \\
\hline
\end{tabular}

Table 4. Results

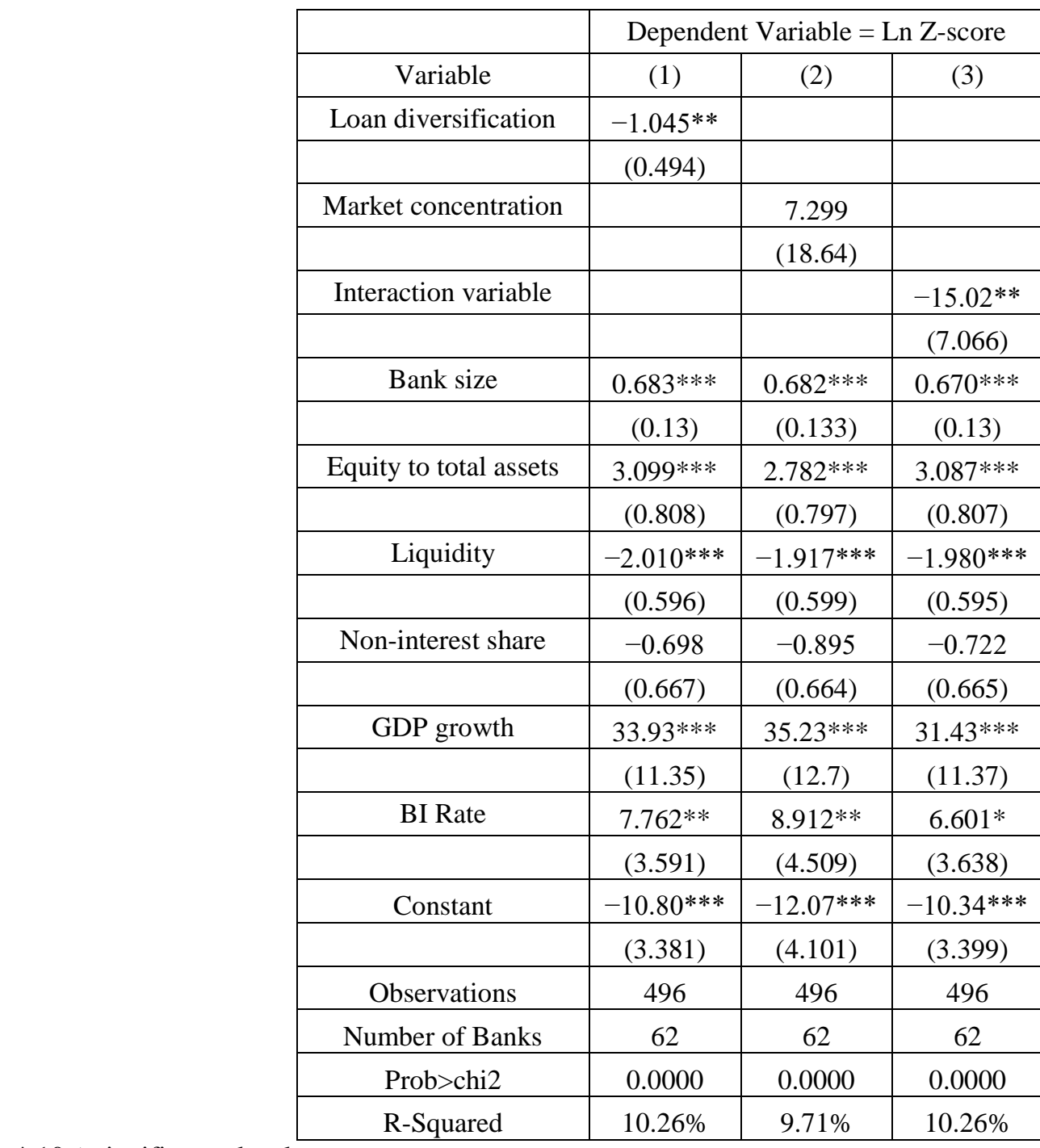

* $10 \%$ significance level

** 5\% significance level, and

*** $1 \%$ significance level 
Based on the regression results for model 3, the interaction variable shows negative and significant results. The significant results indicate that the effect of loan diversification on bank stability can be different for banks in markets that are more concentrated and less concentrated. The negative coefficient indicates that the loan diversification strategy reduces bank stability in both concentrated and non-concentrated markets. However, in concentrated markets, the coefficient of diversification of loans tends to be higher than the coefficient when in a less concentrated market.

The transaction cost theory indicates that the optimal level of diversification for a company is determined by weighing the economic benefits of diversification and the bureaucratic costs of managing the portfolio (Jones \& Hill 1988; Shim 2019). The theory also indicates that companies reduce their level of diversification if the competitive environment tends to increase costs to manage diversified activities. According to Shim (2019), when competition in a company's core business increases, yields from managing non-core businesses tend to decline. In other words, if a bank diversifies into a more competitive or less concentrated market, the bank tends to be riskier.

Based on the regression results, a bank's size consistently affects its stability in a positive direction and at a $1 \%$ significance level. Thus, a larger bank is more stable. The results of this study are similar to those of Kohler (2015) and Shim (2019), which also indicate a positive relationship between size and bank stability. Larger banks are believed to have greater capabilities and opportunities to diversify their income sources and have more experience managing risks and, thus, more stable performance.

The regression test results also show that the ratio of total equity to total assets has a positive influence on a bank's stability at a $1 \%$ significance level. The higher ETA value indicates that banks have better capital and, thus, low risk from a capital perspective. Curi et al. (2015) also argued that a healthy capital ratio shows good efficiency. Thus, banks have a low cost of bearing debt. Kohler (2015) also found that banks that are more at risk tend to have lower capital ratios.

Another control variable, liquidity, has a negative influence on bank stability at the $1 \%$ significance level. According to Brandao-Marques et al. (2013), higher liquidity can also increase the bank's risk appetite, encouraging banks to take greater risks. Supporting Brandao-Marques' opinion, Lucchetta (2007) found that increasing liquidity encourages banks to invest in risky assets. In contrast to liquidity, the amount of noninterest income consistently does not significantly affect banks' stability. Non-significant results can also be found in Leroy and Lucotte (2016), which used a sample of listed banks in Europe.
The regression results for all three models showed that bank stability increases when gross domestic product growth and the Bank Indonesia rate increase. This variable indicates a consistent $1 \%$ significance level for each model. GDP growth is a common indicator used to measure a country's economic strength. A country with a better economic condition has banks with higher returns and more stable retained earnings.

\section{CONCLUSION}

The objective of this research is to analyze the effects of loan diversification, market concentration, and the interaction between those two variables on bank stability in Indonesia. In general, the stability of commercial banks in Indonesia has decreased as diversified loans based on type of use have increased. The implication is that loan diversification does not guarantee superior performance for banks in Indonesia. Banks in developing countries such as Indonesia need to carefully consider whether their choice to diversify also influences their effectiveness in monitoring credit disbursed. If banks want to diversify, they also need to invest more in risk management to ensure effectiveness and efficiency in monitoring loan quality.

This study also empirically proved that banking market concentration does not significantly affect bank stability in Indonesia. This result implies that standard measurements of market concentration, such as HHI, may be less ideal in representing market concentration in Indonesia. Moreover, the paradigms of "concentration-stability" and "concentration-fragility" do not match what happened with Indonesian banking. In terms of interaction effects, the stability and risk of diversifying banks may differ in concentrated and less concentrated markets. The results of this study indicate that banks that diversify into less concentrated markets tend to be riskier than banks that diversify in more concentrated markets. Therefore, Indonesian banks also need to consider the conditions of market concentration when deciding to diversify.

\section{RESEARCH LIMITATION}

This study uses a credit structure based on the type of use when defining loan diversification. The sample used is also very limited, given the limitations in bank data that provide information on credit structure. Using a larger number of samples and different types of credit classifications may show better results. In addition, given data limitations and ease of calculation, this study only uses the Z-score as a proxy for bank stability. Further research should improve on the proxy used to measure bank stability, such as using a probability of default measure or other bank risk measures. 


\section{ACKNOWLEDGMENTS}

This work was supported by the PITMA Research Grant 2019 provided by the University of Indonesia.

\section{REFERENCES}

[1] Acharya, V. V. and Naqvi, H. The seeds of a crisis: A theory of bank liquidity and risk-taking Over the business cycle. NYU Working Paper, 2451/29886, 2010.

[2] Acharya, V., Hasan, I. and Saunders, A. 'Should banks be diversified? Evidence from individual bank loan portfolios'. The Journal of Business, 79(3), 2006, pp. 1355-1412.

[3] Adzobu, L. D., Agbloyor, E. K. and Aboagye, A. 'The effect of loan portfolio diversification on banks' risks and return: evidence from an emerging market'. Managerial Finance, 43(11), 2017, 12741291.

[4] Allen, F. and Gale, D. 'Competition and financial stability'. Journal of Money, Credit, and Banking, 36(3b), 2004, pp. 453-480.

[5] Ashraf, D., Ramady, M. and Albinali, K. Financial fragility of banks, ownership structure and income diversification: empirical evidence from the GCC region. Research in international business, 2016, 756-68.

[6] Baele, L., De Jonghe, O. and Vander Vennet, R. 'Does the stock market value bank diversification?' Journal of Banking and Finance, 31(7), 2007, pp. 1999-2023.

[7] Beck, T., De Jonghe, O. and Schepens, G. 'Bank competition and stability: cross-country heterogeneity'. Journal of Financial Intermediation, 22(2), 2013, pp. 218-244.

[8] Berger, A. N., Hasan, I. and Zhou, M. 'The effects of focus versus diversification on bank performance: evidence from Chinese banks'. Journal of Banking and Finance, 34(7), 2010, pp. 1417-1435.

[9] Boot, A. W. and Thakor, A. V. 'The accelerating integration of banks and markets and its omplications for regulation' Oxford handbook of banking. Oxford University Press, Oxford, 2009.

[10] Boyd, J. H. and De Nicoló, G. 'The theory of bank risk-taking and competition revisited'. Journal of Finance, 60(3), 2005, pp. 1329-1343.

[11] Chen, M., Jeon, B. N., Wang, R. and Wu, J. 'Corruption and Bank risk-taking: evidence from emerging economies'. Emerging Markets Review, 24, 2015, pp. 122-148.
[12] Curi, C., Lozano V., and Zelenyuk V. Foreign bank diversification and efficiency prior to and during the financial crisis: does one business model fit all? BEMPS- Bozen Economics \& Management Paper Series. BEMPS18, Faculty of Economics and management at the Free University of Bozen, 2014.

[13] Demirgüç-Kunt, A. and Huizinga, H. 'Bank Activity and funding strategies: the impact on risk and returns $\boldsymbol{\tau}^{\prime}$. Journal of Financial Economics, 98(3), 2010, pp. 626-650.

[14] Demsetz, R. S. and Strahan, P. E. Journal of Money, Credit and Banking, 29, No. 3, 1997, pp. 300-313.

[15] DeYoung, R. and Torna, G. 'Nontraditional banking activities and bank failures during the financial crisis'. Journal of Financial Intermediation, 22(3), 2013, pp. 397-421.

[16] Hayden, E., Porath, D. and von Westernhagen, N. Does diversification improve the performance of German banks? Evidence from individual bank loan portfolios. Deutsche Bundesbank, Discussion Paper, Series 2: Banking and Financial Studies, 2006.

[17] Hughes, J. P. and Mester, L. J. 'Bank capitalization and cost: evidence of scale economies in risk management and signaling'. The Review of Economics and Statistics, 80(2), 1998, pp. 314325.

[18] Jensen, M. C. and Meckling, W. H. 'Theory of the firm: managerial behavior, agency costs, and ownership structure'. Journal of Financial Economics, 3(4), 1976, pp. 305-360.

[19] Jiménez, G., Lopez, J. A. and Saurina, J. 'How does competition affect bank risk-taking?' Journal of Financial Stability, 9(2), 2013, pp. 185-195.

[20] Jones, G. R. and Hill., C. W. L. 'Transaction cost analysis of strategy-structure choice'. Strategic Management Journal, 9(2), 1988, pp. 159-172.

[21] Kasman, S. and Kasman, A. 'Bank competition, concentration and financial stability in the Turkish banking industry'. Economic Systems, 39, 2015, p. 16.

[22] Keeley, M. C. 'Deposit insurance, risk and market power in banking'. American Economic Review, 80, 1990, pp. 1183-1200.

[23] Köhler , M. 'Does Non-Interest Income Make Banks More Risky? Retail versus Investment Oriented Banks'. Review of Financial Economics, 23(4), 2014, pp. 182-193. 
[24] Laeven, L. and Levine, R. 'Bank governance, regulation, and risk taking'. Journal of Financial Economics, 93(2), 2009, pp. 259-275.

[25] Leroy, A. and Lucotte, Y. 'Is there A competitionstability trade-off in Eurpean banking?' Journal of International Financial Markets, Institutions and Money, 46, 2016, pp. 199-215.

[26] Lindawati, H. and Chalid, D. A. The impact of competition on bank stability in ASEAN-5. Competition and Cooperation in Economics and Business, 2018.

[27] Lucchetta, M. 'What do data say About monetary policy, bank liquidity and bank risk taking?' Economic Notes, 36(2), 2007, pp. 189-203.

[28] Nguyen, M., Skully, M. and Perera, S. 'Market power, revenue diversification and bank stability: evidence from selected South Asian countries'. Journal of International Financial Markets, Institutions and Money, 22(4), 2012, pp. 897-912.

[29] Rossi, S. P. S., Schwaiger, M. S. and Winkler, G. 'How loan portfolio diversification affects risk, efficiency, and capitalization: A managerial behavior model for Austrian banks'. Journal of Banking and Finance, 33(12), 2009, pp. 22182226.
[30] MishkinS. Mishkin, F. S. 'Financial consolidation: dangers and opportunities'. Journal of Banking and Finance, 23(2-4), 1999, pp. 675-691.

[31] Sanya, S. and Wolfe, S. 'Can banks in emerging economies benefit from revenue diversification?' Journal of Financial Services Research, 40(1-2), 2011, pp. 79-101.

[32] Shim, J. 'Loan portfolio diversification, market structure and bank stability'. Journal of Banking and Finance, 104, 2019, pp. 103-115.

[33] Song, F. and Thakor, A. V. 'Relationship banking, fragility, and the asset-liability matching problem'. Review of Financial Studies, 20(6), 2007, pp. 2129-2177.

[34] Stiroh, K. J. 'Diversification in banking: is noninterest income the answer?' Journal of Money, Credit, and Banking, 36(5), 2004, pp. 853-882.

[35] Tabak, B. M., Fazio, D. M. and Cajueiro, D. O. 'The relationship between banking market competition and risk-taking: do size and capitalization matter?' Journal of Banking and Finance, 36(12), 2012, pp. 3366- 3381.

[36] Winton, A. Don't put all your eggs in one basket? Diversification and specialization in lending. Working Paper. University of Minnesota, MN. 